\title{
Monitoring of air quality before the Olympic Games Rio 2016
}

\author{
LUCIANA M.B. VENTURA ${ }^{1,2}$, MICHELLE B. RAMOS ${ }^{2}$, JÉSSICA O. SANTOS ${ }^{2}$ and ADRIANA GIODA ${ }^{1}$ \\ ${ }^{1}$ Pontifícia Universidade Católica do Rio de Janeiro/PUC-Rio, Rua Marquês de \\ São Vicente, 225, Gávea, 22451-900 Rio de Janeiro, RJ, Brazil \\ ${ }^{2}$ Instituto Estadual do Ambiente/INEA, Avenida Venezuela, 110, Saúde, 20081-312 Rio de Janeiro, RJ, Brazil
}

Manuscript received on December 5, 2017; accepted for publication on July 9, 2018

\begin{abstract}
How to cite: VENTURA LMB, RAMOS MB, SANTOS JO AND GIODA A. 2019. Monitoring of air quality before the Olympic Games Rio 2016. An Acad Bras Cienc 91: e20170984. DOI 10.1590/0001-3765201920170984.

Abstract: For the accomplishment of Olympic and Paralympic Games in Rio de Janeiro city (Rio 2016), the government of the Rio de Janeiro state has undertaken to monitor air quality before and during the events. In Beijing, China, and Athens, Greece, the air quality was monitored in Olympic venues in order to evaluate the athletes' performance in relation to the environment in which they were exposed. This study has the same proposal to Rio de Janeiro, Brazil. The air quality scenario of the three previous years (2013, 2014, 2015) of Rio 2016 was considered. Coarse (PM10) and fine (PM2.5) particles and O3 were monitored continuously on the stations located near to competition venues, as required by International Olympic Committee (IOC). The levels registered ranged from 6 to $96 \mu \mathrm{g} \mathrm{m}-3$ for PM10, 1 to $44 \mu \mathrm{g} \mathrm{m}-3$ for PM2.5 and 121 to $269 \mu \mathrm{g} \mathrm{m}-3$ for O3. These concentrations exceeded the national and international air quality standards. These high concentrations are associated with uncountable civil works to build Olympic arenas and the urban mobility's improvement. However, the concentrations for all the pollutants monitored in Rio de Janeiro city were in lower concentrations than in Beijing Olympic Games 2008.
\end{abstract}

Key words: Air quality, $\mathrm{PM}_{10}, \mathrm{PM}_{2.5}, \mathrm{O}_{3}$, Olympic Games.

\section{INTRODUCTION}

The Olympic and Paralympic Games were hosted in Rio de Janeiro city, between August $5^{\text {th }}$ and September $18^{\text {th }}$ of 2016 . Rio de Janeiro is one of the 30 biggest megacities in the world, being the second biggest city in Brazil and third in South America. This city has about six million inhabitants and a population density of $5.265 \mathrm{hab}$ $\mathrm{km}^{-2}$ (IBGE 2012). It has a fleet of 2.6 million vehicles (DETRAN-RJ 2014) - almost one vehicle

Correspondence to: Adriana Gioda

E-mail: agioda@puc-rio.br

ORCid: https://orcid.org/0000-0002-5315-5650 for every three inhabitants - and the second highest participation in the Gross Domestic Product (GDP) of the country (IBGE 2012).

With very similar characteristics to Athens, Greece, Rio de Janeiro city is also surrounded by the sea and mountains, which have an enormous impact in the pollutants atmospheric dispersion and, consequently, in the air quality. Although Rio de Janeiro is a coastal city, which helps the natural ventilation, its steep topography, parallel to the cost line, makes the air circulation more difficult (Soluri et al. 2007, Godoy et al. 2009). Another factor that influences the city's air quality is the irregular land- 
use. The city's climate is subtropical, with intense solar radiation and high temperatures, which favors the formation of secondary photochemical pollutants.

Rio de Janeiro city has undergone many changes, mainly in infrastructure and urban mobility, due to the World Cup and Olympic Games. The infrastructure works throughout the city began in 2008. Works included expansion of the international airport (2008) and hotel network (2010), Maracanã stadium reform (2010), construction of subway (line 4) (2010) and exclusive bus routes (BRT) (2011) (Ventura et al. 2016, 2017b).

At each new choice of the Olympic Games' host cities, the demands imposed by the International Olympic Committee (IOC) about the monitoring air quality have increased. The chosen city must monitor air quality at least three years before the Olympics and inform the population the air quality indexes. The pollutant levels must be within the national standards during the Games to avoid influences on the athletes' performance. It is due to new studies about air quality and health (Brook et al. 2010, Rundell 2012). One of these studies was performed by the American Heart Association (AHA), which advised against the practice of intense exercises in the presence of unsatisfactory air quality, even though the sportive medicine societies do not recommend cares with the practice of exercises in polluted places (Brook et al. 2010). Rundell (2012) evaluated the effect of pollution in athletes' performance and concluded that the practice of physical exercises in environments with high levels of pollutants reduces sharply the pulmonary and vascular function both in asthmatic individuals and healthy ones. Therefore, the practice of exercises in long-term in polluted places is associated to the reduction of pulmonary function, being able to induce vascular dysfunction, due to the systemic oxidative stress and in the nasal passages, and, consequently, reduce the athletes' performance (Rundell 2012).

Particulate matter (PM) and $\mathrm{O}_{3}$ are between the six pollutants $\left(\mathrm{CO}, \mathrm{Pb}, \mathrm{SO}_{2}, \mathrm{NO}_{2}\right.$, and $\left.\mathrm{O}_{3}\right)$ used to assess air quality and avoid damage to health and ecosystems (U.S.EPA 2012). PM is considered the main pollutant involved in respiratory and cardiac problems (Dominici et al. 2006). Ozone can also have a negative impact on public health when present in the higher and moderate levels in the atmosphere (Luna et al. 2014). In high concentrations, these pollutants can reduce the athletes' physical capacity and can cause discomfort for the population (Brook et al. 2010). Therefore, monitoring the air quality is essential to the athlete's performance and population health.

In 2011 Environmental Institute of Rio de Janeiro state (INEA) installed air quality monitoring stations $\left(\mathrm{PM}_{10}, \mathrm{PM}_{2.5}\right.$ and $\left.\mathrm{O}_{3}\right)$ and meteorology surroundings of the competition venues of Olympic Games (Rio 2016), reason for which were nominated as Olympic Stations (Supplementary Material - Table SI) (INEA 2016a, Ventura et al. 2017b). The Olympic Stations and the competition venues can be visualized in Figure 1.

The goal of this study is to evaluate the results obtained by INEA and IOC regarding the air quality monitoring in Rio de Janeiro city 3 years before the Olympic and Paralympic Games (Rio 2016), in order to infer about health effects.

\section{MATERIALS AND METHODS}

In order to execute the monitoring of air quality in the Olympic and Paralympic Games arenas, INEA standardized measurement to determine the pollutant levels $\left(\mathrm{PM}_{10}, \mathrm{PM}_{2.5}\right.$ and $\left.\mathrm{O}_{3}\right)$. The air quality monitoring stations were distributed in four sportive regions: Recreio dos Bandeirantes and Jacarepaguá (Barra da Tijuca), Gericinó and Campo dos Afonsos (Deodoro), Lagoa, Leblon and Urca (Copacabana), as well as Maracanã, 


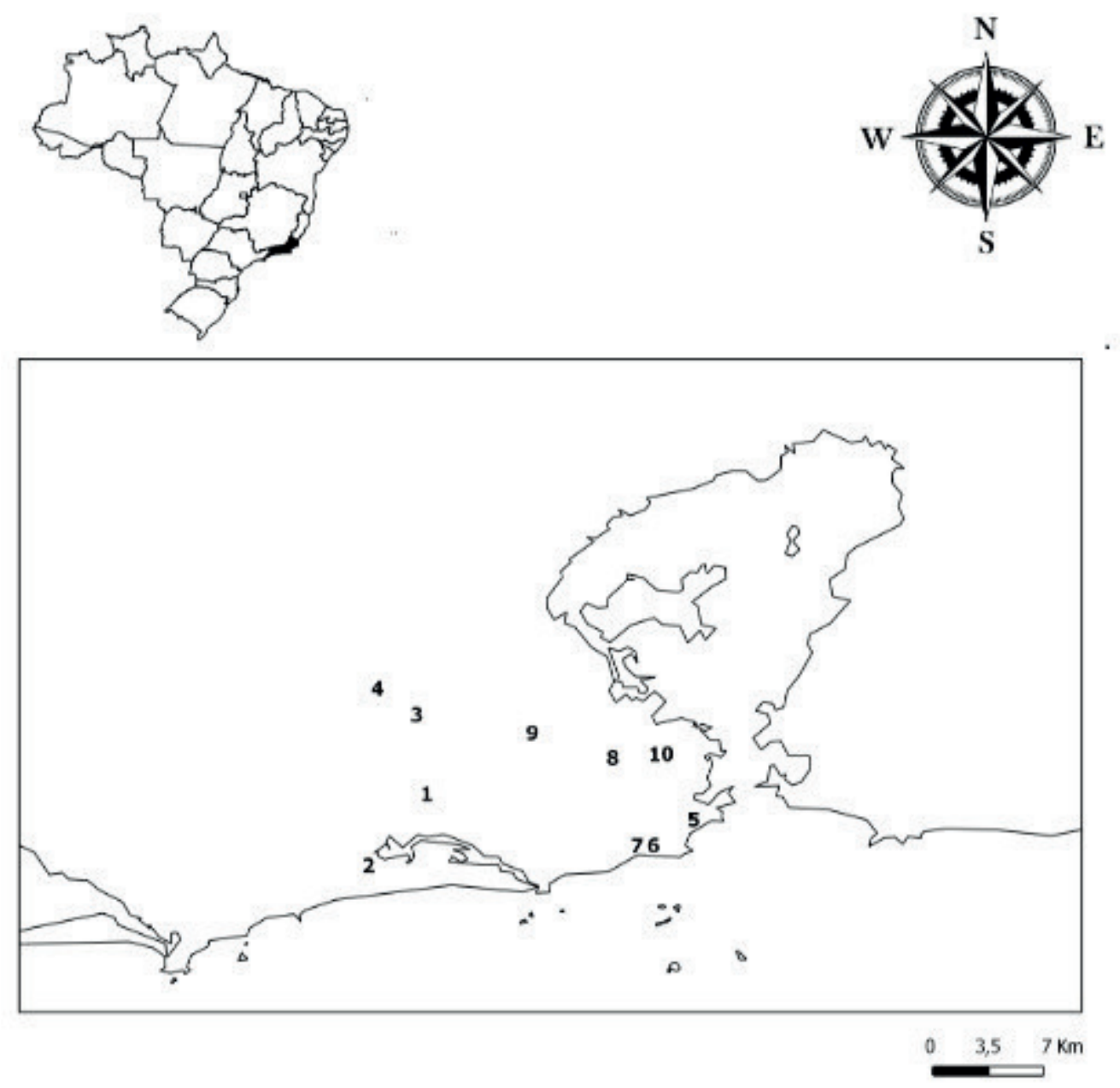

Figure 1 - Map of Olympic stations distributed in Rio 2016 competition venues: 1 - Jacarepaguá; 2 - Recreio dos Bandeirantes; 3 - Campos dos Afonsos; 4 - Gericinó; 5 - Urca; 6 - Leblon; 7 - Lagoa; 8 - Maracanã; 9 Engenho de Dentro; 10 - Downtown. Source: Adapted from Ventura et al. 2016.

Engenho de Dentro and Downtown (Maracanã). Table I presents the sampling sites and parameters monitored in each one. This study analyzed data obtained through 3 years (2013, 2014 and 2015) before the Olympic Games.

The automatic stations perform continuous measurements of $\mathrm{O}_{3}$ concentrations dispersed in the air, delivering hourly averages. Ozone was monitored following the U.S.EPA Reference Method EQOA-0506-160 and measured with the equipment O342M (Environment S.A, France). The semiautomatic stations monitor particulate matter $\left(\mathrm{PM}_{2.5}\right.$ and $\left.\mathrm{PM}_{10}\right)$ concentrations in the air for 24 hours every six days, covering every day of the week, including weekends, as well as rainy days cover all situations as soon as possible (INEA 2016a). The particulate matter samples were collected using high volume samplers (Model AGVMP252 for $\mathrm{PM}_{2.5}$ and Model AGVMP10 for $\mathrm{PM}_{10}$, Energética, Brazil). These samplers retained PM in glass fiber filters (Millipore, USA), approximately $3 \mathrm{~m}$ above ground level with a volumetric flow rate of $0.019 \mathrm{~m}^{3} \mathrm{~s}^{-1}$. The mass of particulate matter was obtained by the gravimetric 
analysis. The filter mass was weighed before and after collection on an analytical balance (Mettler E., Zürich. Switzerland, $\pm 0.0001 \mathrm{~g}$ ), as described in the Brazilian Technical Standard (NBR 13412) method.

To better understand some air quality levels, it was shown in Table SII the meteorological data of each Olympic stations from 2013-2015, such as temperature $(\mathrm{T})$, relative humidity $(\mathrm{RH})$, wind speed (WS) and direction (WD). The meteorological data used in the statistical analyzes were averages of $24 \mathrm{~h}$. Besides, it was showed the preferential wind direction by Wind Roses (Figure S1).

\section{STATISTICAL ANALYSES}

To verify the correlation between the pollutants measured by the Olympic station and meteorological data, the correlation matrix was used. The Pearson correlation coefficient quantifies the association between two variables. When the correlation coefficient is greater than 0.3 there is correlation between the variables. This technique was applied to the data of $\mathrm{PM}_{10}, \mathrm{PM}_{2.5}, \mathrm{O}_{3}, \mathrm{~T}, \mathrm{RH}$ and WS, for the average daily data for criteria pollutants concentrations and meteorological parameters, except for ozone which adopted maximum daily concentration. Besides, boxplot was used to represent the distribution of the $\mathrm{PM}_{10}$ and $\mathrm{PM}_{2.5}$ concentrations for each sport regions from 2013 to 2015 .

\section{RESULTS AND DISCUSSION}

In Brazil, the air quality standards are set by the National Environment Council through Resolution n. 03, published in 1990 (CONAMA 1990). The annual mean $\mathrm{PM}_{10}$ concentration standard is $50 \mu \mathrm{g}$ $\mathrm{m}^{-3}$ and the daily concentration standard is $150 \mu \mathrm{g}$ $\mathrm{m}^{-3}$ and for $\mathrm{O}_{3}$ the hourly concentration standard is $160 \mu \mathrm{g} \mathrm{m}^{-3}$. Brazilian legislation has not been updated since its creation in the 1990s. Presently, this resolution is being reviewed, and the limits for $\mathrm{PM}_{2.5}$ will be included. Although the Brazilian legislation has not adopted daily and annual air quality standards to $\mathrm{PM}_{2.5}$ yet, this pollutant has been monitored for semiautomatic stations in Rio de Janeiro state since 2011 (Ventura et al. 2017b). This study used the air ambient standards (AAS) set by U.S.EPA to evaluate the results because these standards include health criteria and also socioeconomic aspects. For the short-period exposure, it was adopted the daily standard of $35 \mu \mathrm{g} \mathrm{m}^{-3}$ and for long period, the annual standard of $12 \mu \mathrm{g} \mathrm{m}^{-3}$.

\section{PARTICULATE MATTER}

The annual average $\mathrm{PM}_{2.5}$ concentrations measured from 2013 to 2015 in Rio de Janeiro city ranged from 6 to $20 \mu \mathrm{g} \mathrm{m}^{-3}$. These levels were lower than the ones registered in Beijing, China, during the Olympic Games $\left(46.7 \mu \mathrm{g} \mathrm{m}^{-3}\right)$ and Pre-Olympic period $\left(72.3 \mu \mathrm{g} \mathrm{m}^{-3}\right)$, even after the adoption of several measures to control the emission of pollutants ( $\mathrm{Li}$ et al. 2010). These averages are within the range of the other Latin American cities, e.g. Buenos Aires, Argentina $\left(15 \mu \mathrm{g} \mathrm{m}^{-3}\right)$ and Santiago, Chile $\left(30 \mu \mathrm{g} \mathrm{m}^{-3}\right)$ (Jhun et al. 2013, Arkouli et al. 2010).

The sampling sites located close to urban roads are influenced by heavy traffic (Table II). Urca's station was the sampling point with less vehicular influence while Lagoa was more impacted. The annual average $\mathrm{PM}_{2.5}$ concentrations observed at Maracanã ranged from 6 to $13 \mu \mathrm{g}$ $\mathrm{m}^{-3}$, which are similar to the previous study from 2003 to 2005 (9.8 to $11 \mu \mathrm{g} \mathrm{m}^{-3}$ ) (Soluri et al. 2007, Godoy et al. 2009). On the other hand, previous studies performed in Recreio dos Bandeirantes registered lower concentrations of $\mathrm{PM}_{2.5}(7.7 \mu \mathrm{g}$ $\mathrm{m}^{-3}$ ) (Soluri et al. 2007, Godoy et al. 2009) than in this one (11 to $16 \mu \mathrm{g} \mathrm{m}^{-3}$ ). Since 2008 , this site has been received more influence of heavy traffic due to the construction of an expressway for bus circulation (BRT-TransOeste) and constructions 
TABLE I

Air quality and meteorology Olympic monitoring station network.

\begin{tabular}{|c|c|c|c|c|}
\hline \multirow{2}{*}{ Monitoring station } & \multirow{2}{*}{ Sport region } & \multicolumn{2}{|c|}{ Coordinate } & \multirow{2}{*}{$\begin{array}{l}\text { Air Quality } \\
\text { Parameters }\end{array}$} \\
\hline & & Longitude & Latitude & \\
\hline \multirow[t]{2}{*}{ Jacarepaguá } & & $-22,93647^{\circ}$ & $-43,371727^{\circ}$ & $\mathrm{O}_{3}$ \\
\hline & Barra da Tijuca & & & \\
\hline Recreio dos Bandeirantes & & $-22,98928^{\circ}$ & $-43,414962^{\circ}$ & $\mathrm{O}_{3}$ and $\mathrm{PM}_{2.5}$ \\
\hline \multirow[t]{2}{*}{ Campo dos Afonsos } & & $-22,87861^{\circ}$ & $-43,379278^{\circ}$ & $\mathrm{O}_{3}$ and $\mathrm{PM}_{10}$ \\
\hline & Deodoro & & & \\
\hline Gericinó & & $-22,85933^{\circ}$ & $-43,408049$ & $\mathrm{O}_{3}$ and $\mathrm{PM}_{10}$ \\
\hline Urca & & $-22,95534^{\circ}$ & $-43,175882^{\circ}$ & $\mathrm{O}_{3}$ and $\mathrm{PM}_{2.5}$ \\
\hline Leblon & Copacabana & $-22,78423^{\circ}$ & $-43,222986^{\circ}$ & $\mathrm{O}_{3}$ and $\mathrm{PM}_{10}$ \\
\hline Lagoa & & $-22,97449^{\circ}$ & $-43,217642^{\circ}$ & $\mathrm{O}_{3}$ and $\mathrm{PM}_{2.5}$ \\
\hline Maracanã & & $-22,91039^{\circ}$ & $-43,235731^{\circ}$ & $\mathrm{O}_{3}, \mathrm{PM}_{10,} \mathrm{PM}_{2.5}$ \\
\hline Engenho de Dentro & Maracanã & $-22,89182^{\circ}$ & $-43,294420^{\circ}$ & $\mathrm{O}_{3}$ and $\mathrm{PM}_{2.5}$ \\
\hline Downtown & & $-22,90739^{\circ}$ & $-43,195327^{\circ}$ & $\mathrm{O}_{3}$ \\
\hline
\end{tabular}

Source: INEA (2016).

of Arenas (Sport Parks) and Villages' Athletics for the Olympic Games (Ventura et al. 2016, 2017b), resulting in high levels of pollutants.

In 2014, the annual average $\mathrm{PM}_{2.5}$ concentrations were the highest registered in all sites. For this year, Lagoa, Engenho de Dentro, Maracanã and Recreio dos Bandeirantes levels exceeded the annual air quality standard adopted by U.S.EPA $\left(12 \mu \mathrm{g} \mathrm{m}^{-3}\right)$. On the other hand, the levels for all sites decreased in 2015. These data show the influence of the civil works in the air quality during 2014. By 2015, the works were almost completed, therefore the levels decreased. However, the annual average $\mathrm{PM}_{2.5}$ concentrations in the last three years did not exceed the U.S.EPA AAS.

$\mathrm{PM}_{10}$ annual averages for all sampling sites are present in Table III. In Campo dos Afonsos, Gericinó, Leblon sites were registered annual average concentration below the limit $\left(50 \mu \mathrm{g} \mathrm{m}^{-3}\right)$
TABLE II

Annual average $P M_{2.5}$ concentrations in Rio de Janeiro from 2013 to 2015.

\begin{tabular}{|c|c|c|c|}
\hline \multicolumn{4}{|c|}{ Annual average $P M_{2.5}$ concentration $\left(\mu \mathrm{g} \mathrm{m}^{-3}\right)$} \\
\hline Sampling site & 2013 & 2014 & 2015 \\
\hline Urca & 6 & 11 & 10 \\
\hline Lagoa & 10 & 20 & 14 \\
\hline Recreio dos Bandeirantes & 13 & 16 & 11 \\
\hline Engenho de Dentro & $*$ & 17 & 12 \\
\hline Maracanã & 6 & 13 & 11 \\
\hline
\end{tabular}

*Did not reach $50 \%$ representativeness.

TABLE III

Annual average $\mathbf{P M}_{10}$ concentrations in Rio de Janeiro from 2013 to 2015.

\begin{tabular}{lccc}
\hline \multicolumn{4}{c}{ Annual average $\mathbf{P M}_{\mathbf{1 0}}$ concentration $\left(\boldsymbol{\mu g ~ \mathbf { ~ m } ^ { - 3 } )}\right.$} \\
\hline \multicolumn{1}{c}{ Sampling site } & $\mathbf{2 0 1 3}$ & $\mathbf{2 0 1 4}$ & $\mathbf{2 0 1 5}$ \\
\hline Campo dos Afonsos & 21 & 36 & 30 \\
Gericinó & 23 & 35 & 31 \\
Leblon & 22 & 41 & 44 \\
Maracanã & 43 & 58 & 61 \\
\hline
\end{tabular}


established by CONAMA and U.S.EPA AAS. Only Maracanã station presented averages higher than Brazilian legislation (58 and $61 \mu \mathrm{g} \mathrm{m}^{-3}$ ). The high $\mathrm{PM}_{10}$ levels recorded on this site are related to the stadium renovation works.

As observed in Ventura et al. (2017a) study in Downtown, Copacabana and Maracanã sites, in all sport regions were verified a negative relationship between RH and T (Table IV). The negative value means that these variables are inversely proportional, i.e., when the temperature increases an expansion in air volume occurs, resulting in a decrease in relative humidity.

During the three years of monitoring before the Olympic Games in Copacabana, Maracanã and Deodoro regions, the daily $\mathrm{PM}_{10}$ concentrations varied from 6 to $96 \mu \mathrm{g} \mathrm{m}^{-3}$, which are lower than Brazilian and U.S.EPA guidelines $\left(150 \mu \mathrm{g} \mathrm{m}^{-3}\right)$. In the same period, daily $\mathrm{PM}_{2.5}$ concentrations varied from 1 to $44 \mu \mathrm{g} \mathrm{m}^{-3}$ in Barra da Tijuca and Copacabana regions. In the Maracanã region, on the other hand, the concentrations varied from 2.5 to $87 \mu \mathrm{g} \mathrm{m}^{-3}$. These results enhance the influence of the sea breeze in this pollutant dispersion, as well as the characteristic of the emission source in the concentration levels (vehicles, industries, marine aerosols, and others). In these sites, the levels exceeded the U.S.EPA AAS $(35 \mu \mathrm{g}$ $\left.\mathrm{m}^{-3}\right)$. Copacabana region is close to the sea and Guanabara Bay, which favors air entrance in the continent and consequently, atmospheric pollutants dispersion (Ventura et al. 2017a). For this reason, lowest monthly mean concentrations for both $\mathrm{PM}_{10}$ and $\mathrm{PM}_{2.5}$ were observed.

From 2013 to 2015, an increase in the annual average $\mathrm{PM}_{10}$ concentrations was verified in all sampling sites (Table III). The same happened in Athens, where this behavior was associated with the significant increase of civil works (buildings, roads, sportive installations etc.) to the 2004 Olympic Games, which may have caused an increase of $\mathrm{PM}_{10}$ levels by the emission or resuspension of dust by the heavy vehicles that worked on the constructions (Vassilakos et al. 2005). The annual average $\mathrm{PM}_{10}$ concentration $\left(21-61 \mu \mathrm{g} \mathrm{m}^{-3}\right)$ verified on the Rio de Janeiro's Olympic stations were very similar to Athens in the period of 2001 to 2004 (30 - $60 \mu \mathrm{g}$ $\mathrm{m}^{-3}$ ) (Gryparis et al. 2014) and much smaller than the ones registered in Beijing between 2007 and 2008 (124 - $152 \mu \mathrm{g} \mathrm{m}^{-3}$ ) (He et al. 2016).

According to the Atmospheric Emissions Inventory of the Metropolitan Region of Rio de Janeiro (FEEMA 2004), the vehicles are responsible for $40 \%$ of $\mathrm{PM}_{10}$ emissions. Recent inventory (SEA 2011) estimated that $91 \%$ of the total vehicle emissions are generated by diesel burning.

Monthly data of particulate matter are a good indicator of atmospheric pollution, not only because it shows a direct standard measure for the concentration of dust in the air, but also because of direct relation to the human health (Leys et al. 2011). $\mathrm{PM}_{10}$ seasonality was also studied by Gioda et al. (2016), who had already verified through the time series analysis of this pollutant in Rio de Janeiro city, that there was a trend to increase during the austral wintertime (June 21 to September 21). This trend was related to low rainfall and air mass stagnation. Therefore, the Olympics occurred during the period with higher pollutant levels. This is worrying because, during the exercise practice, the quantity of fine particles deposited in the respiratory tract is inversely proportional to its size. In other words, the smaller the particles, the bigger the quantity deposited, which during a physical practice can come to be five times superior to the ones registered when the body is resting (Daigle et al. 2003).

Figure S2 presents box plots for the distribution of $\mathrm{PM}_{10}$ and $\mathrm{PM}_{2.5}$ concentrations for each sport regions from 2013 to 2015. It was observed that the $\mathrm{PM}_{10}$ data set was very similar. However, in Maracanã $\mathrm{PM}_{2.5}$ concentrations showed a large variation in its data set, due some days in this region 
TABLE IV

Pearson correlation matrix of meteorological variables, $\mathrm{PM}_{2.5}, \mathrm{PM}_{10}$ and $\mathrm{O}_{3}$ for each sport region from 2013 to 2015 (the bold values are significant statistically $(>0.30)$.

\begin{tabular}{|c|c|c|c|c|c|c|c|}
\hline Sport regions & Variables & $\mathrm{O}_{3}$ & $\mathbf{P M}_{2.5}$ & $\mathbf{P M}_{10}$ & WS & $\mathbf{T}$ & RH \\
\hline \multirow{5}{*}{ Barra } & $\mathrm{O}_{3}$ & 1 & 0.34 & - & 0.01 & 0.26 & -0.29 \\
\hline & $\mathrm{PM}_{2.5}$ & 0.34 & 1 & - & -0.27 & 0.11 & -0.21 \\
\hline & WS & 0.01 & -0.27 & - & 1 & -0.00 & -0.10 \\
\hline & $\mathrm{T}$ & 0.26 & 0.11 & - & -0.00 & 1 & -0.55 \\
\hline & RH & -0.29 & -0.21 & - & -0.10 & -0.55 & 1 \\
\hline \multirow{6}{*}{ Copacabana } & $\mathrm{O}_{3}$ & 1 & 0.40 & 0.41 & 0.13 & 0.39 & -0.36 \\
\hline & $\mathrm{PM}_{2.5}$ & 0.40 & 1 & 0.74 & -0.01 & 0.24 & -0.31 \\
\hline & $\mathrm{PM}_{10}$ & 0.41 & 0.74 & 1 & -0.18 & 0.28 & -0.45 \\
\hline & WS & 0.13 & -0.01 & -0.18 & 1 & 0.08 & -0.25 \\
\hline & $\mathrm{T}$ & 0.39 & 0.24 & 0.28 & 0.08 & 1 & -0.49 \\
\hline & RH & -0.36 & -0.31 & -0.45 & -0.25 & -0.49 & 1 \\
\hline \multirow{5}{*}{ Deodoro } & $\mathrm{O}_{3}$ & 1 & - & 0.30 & 0.03 & 0.50 & -0.49 \\
\hline & $\mathrm{PM}_{10}$ & 0.30 & - & 1 & -0.12 & -0.05 & -0.24 \\
\hline & WS & 0.03 & - & -0.12 & 1 & 0.07 & -0.12 \\
\hline & $\mathrm{T}$ & 0.50 & - & -0.05 & 0.06 & 1 & -0.63 \\
\hline & $\mathrm{RH}$ & -0.48 & - & -0.24 & -0.12 & -0.63 & 1 \\
\hline \multirow{6}{*}{ Maracanã } & $\mathrm{O}_{3}$ & 1 & 0.34 & 0.42 & 0.08 & 0.62 & -0.50 \\
\hline & $\mathrm{PM}_{2.5}$ & 0.34 & 1 & 0.80 & -0.13 & 0.23 & -0.29 \\
\hline & $\mathrm{PM}_{10}$ & 0.42 & 0.80 & 1 & -0.08 & 0.31 & -0.45 \\
\hline & WS & 0.08 & -0.13 & -0.08 & 1 & 0.086 & -0.08 \\
\hline & $\mathrm{T}$ & 0.62 & 0.23 & 0.31 & 0.086 & 1 & -0.63 \\
\hline & RH & -0.50 & -0.29 & -0.45 & -0.08 & -0.63 & 1 \\
\hline
\end{tabular}

the air quality was influenced by power generator as traffic.

In Maracanã and Copacabana region were monitored $\mathrm{PM}_{2.5}$ and $\mathrm{PM}_{10}$. When it was applied Pearson Correlation matrix between these pollutants (Table IV), it was observed high correlations (> 0.7). According to Silva et al. (2016), this result indicates that these data are highly related and most likely have the same emission sources and/or similarity in formation and consumption processes.

Figures 2 and 3 presented monthly average $\mathrm{PM}_{10}$ and $\mathrm{PM}_{2.5}$ distributed in the sportive regions to verify the particulate matter behavior on the different seasons, especially in winter, the period of the Olympics. According to the t-student test with $95 \%$ confidence level, the highest concentrations were registered from May to September, as expected, due to the unfavorable conditions to the atmospheric pollutants' dispersion. On the other hand, lower concentrations were measured in November and December, during the rainy season. In Beijing, as well as in Rio de Janeiro city, the winter was also the season less prone to the pollutant's dispersion, resulting in average $\mathrm{PM}_{2.5}$ concentrations of $140( \pm$ 42) $\mu \mathrm{g} \mathrm{m}^{-3}$; while the summer was $92( \pm 25) \mu \mathrm{g} \mathrm{m}^{-3}$ (Lv et al. 2016). However, in Greece in 2003, the average $\mathrm{PM}_{2.5}$ concentrations were lower in winter $\left(15 \mu \mathrm{g} \mathrm{m}^{-3}\right)$ than in the summer and spring $(25 \mu \mathrm{g}$ $\mathrm{m}^{-3}$ ) (Vassilakos et al. 2005).

Gioda et al. (2016) studied the $\mathrm{PM}_{10}$ performance at several monitoring sites in Rio de Janeiro state from 1998 to 2013, including 


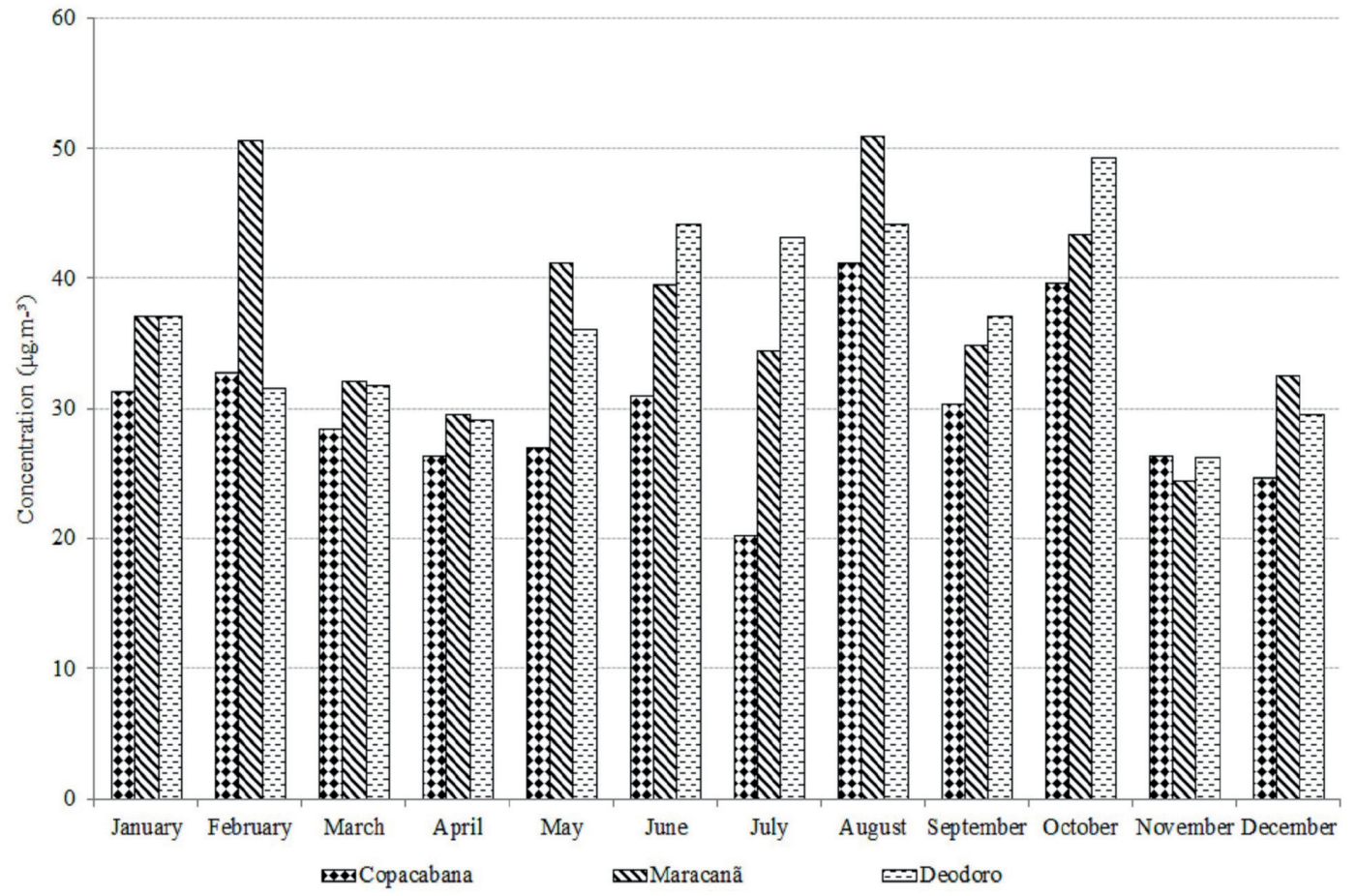

Figure 2 - Monthly average $\mathrm{PM}_{10}$ concentrations by sporting regions during 2013-2015.

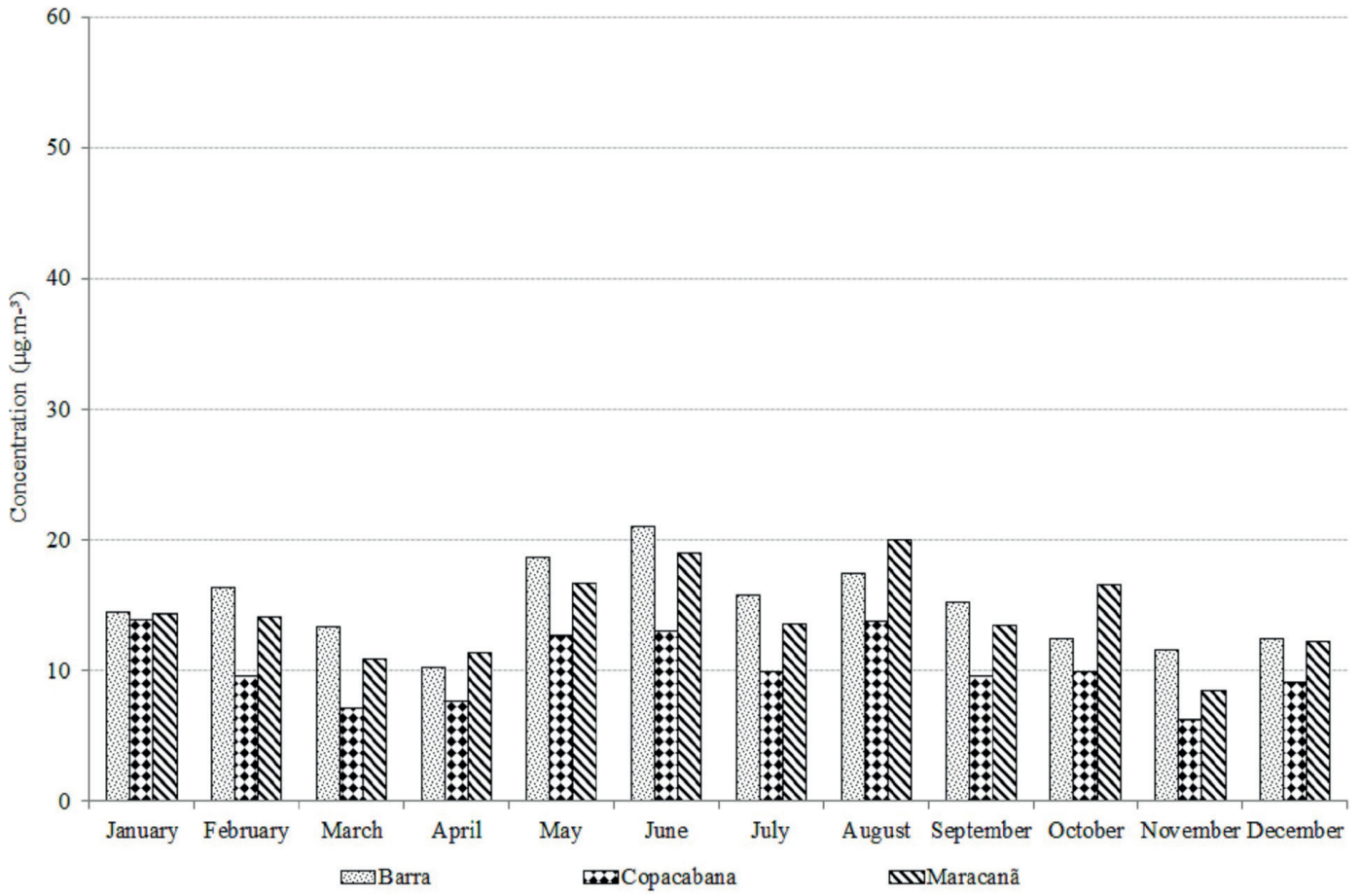

Figure 3 - Monthly average $\mathrm{PM}_{2.5}$ concentrations by sporting regions during 2013-2015. 
Maracanã. The annual average $\mathrm{PM}_{10}$ concentrations registered in Maracanã in this period ranged from 39 to $55 \mu \mathrm{g} \mathrm{m}^{-3}$. In 2014 and 2015 there were increases in concentrations of this pollutant, probably due to infrastructure works. Studies evaluating the toxicity and hospitalization caused by $\mathrm{PM}_{10}$ in Rio de Janeiro city were performed and indicating a strong correlation with health problems (Rodríguez-Cotto et al. 2014, Gioda et al. 2011, Sousa et al. 2012).

OZONE

In Rio de Janeiro city, high ozone concentrations represent the main air pollution problems and have resulted in several national air quality standard violations (Martins et al. 2015, Silva et al. 2016). Table $\mathrm{V}$ presents the maximum hourly ozone concentrations obtained in 2013, 2014 and 2015, and the violations of the Brazilian standard (160 $\mu \mathrm{g} \mathrm{m}^{-3}$ ). In Olympic areas were verified 34, 111 and 49 violations to ozone concentrations from 2013 to 2015 , respectively, where the national standard was exceeded.

Barra and Copacabana regions represented together $16 \%$ of all violations observed in Olympic areas due to land-sea breezes affecting ozone concentrations at coastal sites (Luna et al. 2014), which favors atmospheric pollutants dispersion (Ventura et al. 2017c), reducing these levels.

In all sport regions, ozone showed a positive correlation with $\mathrm{PM}_{2.5}$ and $\mathrm{PM}_{10}$ (Table IV). According to Martins et al. (2015), although PM does not directly participate in the process of ozone formation, environments with higher PM concentrations block solar radiation due to light scattering and decrease the photochemical dissociation of $\mathrm{NO}_{2}$. This photochemical dissociation of $\mathrm{NO}_{2}$ initiates the process of ozone formation by forming atomic oxygen.

Deodoro region presented the highest hourly ozone concentrations compared to other study regions (Table V). This can be explained for the high concentrations of the precursor gases emitted by vehicles in this area, within more than 10 ton NOx and 2 ton VOCs per year (INEA 2016b). Moreover, in this region, a big mountain prevents the pollutant dispersion, as it was also observed by Martins et al. (2015), Tsuruta et al. (2017) and Geraldino et al. (2017) in recent studies in west region in Rio de Janeiro city.

Martins et al. (2015) evaluated three stations (Bangu, Irajá and Campo Grande) in west region in Rio de Janeiro city, located along Avenida Brasil, which is the main traffic route, with more than 50,000 vehicles per day (INEA 2016b). This highway is the same that passes near the air quality station in Deodoro. The researchers concluded that these sites were influenced by vehicle emissions, with no significant influences from stationary sources.

In Bangu station, neighborhood Deodoro region was observed by Silva et al. (2016) the highest ozone concentrations and the largest number of air quality standard exceedances in Rio de Janeiro city in 2012 and 2013. According to Tsuruta et al. (2017), it is justified because this region is characterized by higher temperatures and poor air circulation in comparison to the other regions of the city. Geraldino et al. (2017), who also studied Bangu, concluded that the mountains in the southern and northern part of the west region contribute to the increase of surface temperature and the accumulation of local and transported pollutants. Then, high ozone concentrations are mainly associated with adverse meteorological and topographical conditions.

Ozone episodes, which are when the national standards are exceeded, was verified by Geraldino et al. (2017) in Rio de Janeiro city, in special in Bangu, with more frequency with weak surface winds, wind speeds lower than $2 \mathrm{~m} \mathrm{~s}^{-1}$ and from east (E), similar to observed in Gericinó station in 2013, where occurred the second biggest violation number during 3 monitored years. However, most 
TABLE V

Maximum hourly $\mathrm{O}_{3}$ concentrations and number of overtaking to the air quality standard from 2013 to 2015 in Rio de Janeiro.

\begin{tabular}{|c|c|c|c|c|c|c|}
\hline \multirow[b]{2}{*}{ Sampling site } & \multicolumn{2}{|c|}{2013} & \multicolumn{2}{|c|}{2014} & \multicolumn{2}{|c|}{2015} \\
\hline & $\underset{\text { hourly }\left(\mu \mathrm{g} \mathrm{m}^{-3}\right)}{\operatorname{Maximum}}$ & $\begin{array}{l}\text { number of } \\
\text { overtaking }\end{array}$ & $\begin{array}{c}\text { Maximum } \\
\text { hourly } \\
\left(\mu \mathrm{g} \mathrm{m}^{-3}\right)\end{array}$ & $\begin{array}{l}\text { number of } \\
\text { overtaking }\end{array}$ & $\begin{array}{c}\text { Maximum } \\
\text { hourly } \\
\left(\mu \mathrm{g} \mathrm{m}^{-3}\right)\end{array}$ & $\begin{array}{l}\text { number of } \\
\text { overtaking }\end{array}$ \\
\hline Gericinó & 207 & 1 & 186 & 13 & 160 & 0 \\
\hline $\begin{array}{l}\text { Campo dos } \\
\text { Afonsos }\end{array}$ & 205 & 16 & 234 & 81 & 198 & 18 \\
\hline Maracanã & 144 & 0 & 269 & 12 & 219 & 10 \\
\hline $\begin{array}{l}\text { Engenho de } \\
\text { Dentro }\end{array}$ & 165 & 1 & 181 & 3 & 190 & 8 \\
\hline Downtown & 126 & 0 & 123 & 0 & 121 & 0 \\
\hline Urca & 232 & 8 & 176 & 2 & 252 & 8 \\
\hline Lagoa & 209 & 5 & 143 & 0 & 171 & 3 \\
\hline Leblon & 178 & 2 & 145 & 0 & 170 & 2 \\
\hline Jacarepaguá & N.A & N.A & N.A & N.A & 128 & 0 \\
\hline $\begin{array}{l}\text { Recreio dos } \\
\text { Bandeirantes }\end{array}$ & 234 & 1 & 126 & 0 & 156 & 0 \\
\hline
\end{tabular}

N.A - without sampling.

Olympic stations showed wind direction to susoutheast (SSE) with a wind speed of $1 \mathrm{~m} \mathrm{~s}^{-1}$.

Despite the reduction of sulfur contents in diesel from 500 ppm to 10 ppm from 2011 to 2013 , the introduction of catalysts in the new trucks and the reduction of NOx levels, ozone levels were not affected. A similar observation was done by a group of researchers (Adame et al. 2008, Wilson et al. 2012) who analyzed trends in ozone levels in the European troposphere. They indicated that ozone average levels have been increasing, despite reductions in pollutants, which impact ozone formation. However, they also identified year-byyear variations, caused by climate and weather events, and suggested they could be masking the impact of emission reductions on long-term ozone trends. This study confirmed that the relationship between ozone and its precursors is complicated. It is caused by the fact that meteorological and chemical processes can interact over a remarkably wide range of temporal and spatial scales. Luna et al. (2014) verified in Rio de Janeiro City ozone concentrations are strongly connected to meteorological conditions.

Figure 4 showed the concentration of $\mathrm{O}_{3}$ in hourly average through the 3 years. So as verified by Martins et al. (2015), the $\mathrm{O}_{3}$ concentrations begin to increase after sunrise and peaked between 13 - $15 \mathrm{~h}$, which occurs the most intense solar radiation along with high NOx levels (INEA 2016a). The highest hourly $\mathrm{O}_{3}$ concentrations were measured from November to February, when levels as high as $200 \mu \mathrm{g} \mathrm{m}^{3}$ were registered (Figure 5). High temperatures, low formation of clouds and high incidence of solar radiation are the main reasons for the results obtained. These are common phenomena in this period of the year that naturally helps the formation of $\mathrm{O}_{3}$ in the atmosphere especially in subtropical climate regions, like the Rio de Janeiro city (Silva et al. 2018). The lowest $\mathrm{O}_{3}$ concentrations were observed during the early morning due to weak sunlight as well as the consumption processes prevailing over the forming processes (Martins et al. 2015) 


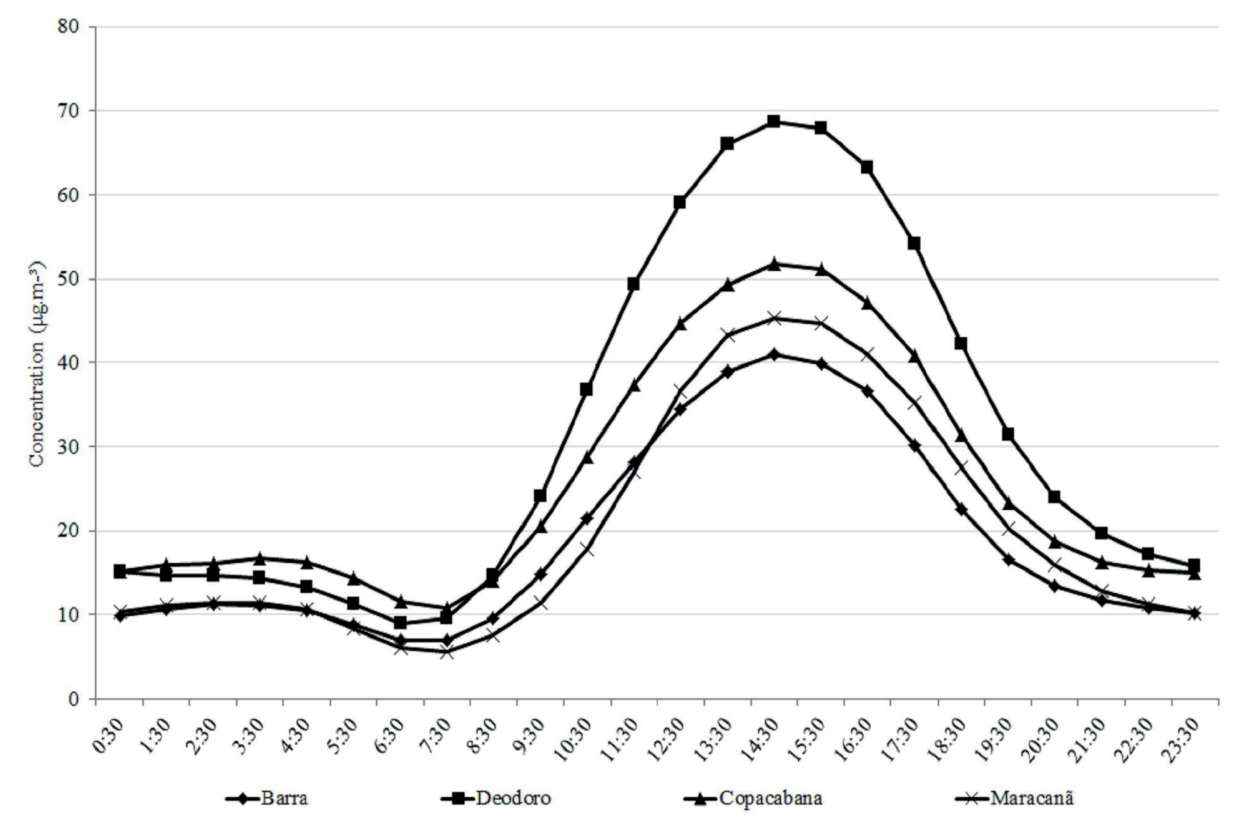

Figure 4 - Hourly average $\mathrm{O}_{3}$ concentrations by sporting regions during 2013-2015.

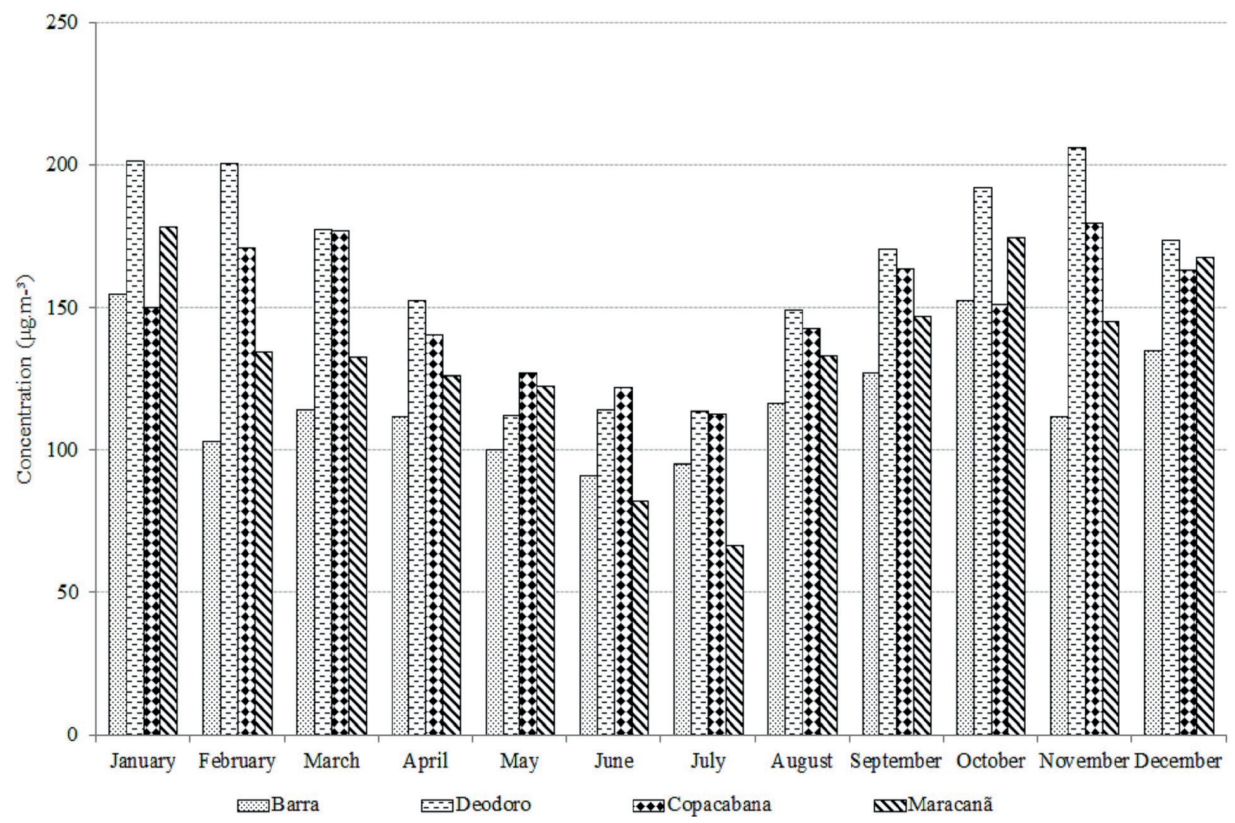

Figure 5 - Monthly maximum hourly $\mathrm{O}_{3}$ concentrations by sporting regions during 2013-2015. 
Important and positive correlations were between $\mathrm{O}_{3}$ and $\mathrm{T}(0.30-0.62)$. The bolded values in Table IV were significant statistically. According to Silva et al. (2016), although the process of ozone formation is initiated photochemically, the correlation was also high for the temperature. This fact was justified because solar radiation and temperature are two meteorological parameters that are interconnected and highly correlated.

Ozone episodes usually occur during hot and sunny days (spring and summer), where strong solar radiation and high temperatures favor the reactions that lead to the ozone formation and various other oxidizing species (Finlayson-Pitts and Pitts 2000). Therefore, these days were not expected during the August of 2016, when the Olympic Games happened, because, in the winter of the last three years (2013, 2014 and 2015), the hourly maximum $\mathrm{O}_{3}$ concentrations did not reach the Brazilian standard $\left(160 \mu \mathrm{g} \mathrm{m}^{3}\right)$.

\section{CONCLUSION}

In order to reduce the impact of air quality on athletes' performance, the State of Rio de Janeiro installed monitoring networks to determine the levels of the main pollutants $\left(\mathrm{PM}_{10}, \mathrm{PM}_{2.5}\right.$, and $\left.\mathrm{O}_{3}\right)$ before and during Olympic Games Rio 2016. This study presents data from 2013 to 2015, a period before Rio 2016, which occurred the main changes in the city's infrastructure (e.g., construction of roads, hotels, arenas etc). According to the results, concentrations of $\mathrm{PM}_{10}$ and $\mathrm{PM}_{2.5}$ had increased in this period (2013-2015) when compared to previous years. This input is mainly caused by the uncountable civil works initiated in Rio de Janeiro city to Olympic arenas construction and urban mobility improvements. This scenario was also verified in other host-cities, like Athens, in Greece, in the preparation the 2004 Olympic Games. However, the concentrations observed for all pollutants monitored in Rio de Janeiro city were much lower than that measured in Beijing, in 2008. But, it is worth to mention, that the $\mathrm{O}_{3}$ and $\mathrm{PM}_{2.5}$ were the pollutants that exceeded the air quality standards more often. Therefore, they were considered the critical pollutants to be controlled during Rio 2016. Lastly, it is expected that with the end of all civil works initiated due to the 2016 Olympic Games, the air quality in Rio de Janeiro city will improve, especially during the sportive event.

\section{ACKNOWLEDGMENTS}

The authors are grateful to the Instituto Estadual do Ambiente (INEA) for the data, Fundação Carlos Chagas Filho de Amparo à Pesquisa do Estado do Rio de Janeiro (FAPERJ) and Conselho Nacional de Desenvolvimento Científico e Tecnológico (CNPq) for financial support.

\section{AUTHOR CONTRIBUTIONS}

LMB Ventura worked on paper design, data interpretation and writing. JO Santos worked on the writing essay and methodology. MB Ramos worked on methodology and data interpretation. A Gioda worked on the final essay and critical review.

\section{REFERENCES}

ADAME JA, LOZANO A, BOLÍVAR JP, DE LA MORENA BA, CONTRERAS J AND GODOY F. 2008. Behavior, distribution and variability of surface ozone at an arid region in the south of Iberian Peninsula (Seville, Spain). Chemosphere 70: 841-849.

ARKOULI M, ULKE A, ENDLICHER W, BAUMBACH G, SCHULTZ E, VOGT U, MÜLLER M, DAWIDOWSKI L, FAGGI A AND WOLF-BENNING U. 2010. Distribution and temporal behavior of particulate matter over the urban area of Buenos Aires. Atmos Pollut Res 1: 1-8.

BROOK RD ET AL. 2010. Particulate matter air pollution and cardiovascular disease: An update to the scientific statement from the American Heart Association. Circulation 121: 2331-2378.

CONAMA - CONSELHO NACIONAL DO MEIO AMBIENTE. 1990. Resolução $n^{\circ} 3$, publicada em 28 de Junho de 1990. Dispõe sobre padrões de qualidade do 
ar, previstos no PRONAR. Disponível em: <http://www. mma.gov.br/port/conama/legiabre.cfm? codlegi $=100>$. (Acesso em Maio, 2016).

DAIGLE CC, CHALUPA DC, GIBB FR, MORROW PE, OBERDÖRSTER G, UTELL MJ AND FRAMPTON MW. 2003. Ultrafine particle deposition in humans during rest and exercise. Inhal Toxicol 15: 539-552.

DETRAN-RJ - DEPARTAMENTO DE TRÂNSITO DO ESTADO DO RIO DE JANEIRO. 2014. Frota de Veículos do Estado do Rio de Janeiro. Disponível em: $<$ http://www. detran.rj.gov.br/_estatisticas.veiculos/index.asp>. (Acesso em Abril, 2016).

DOMINICI F, PENG RD, BELL ML, PHAM L, MCDERMOTT A, ZEGER SL AND SAMET JM. 2006. Fine particulate air pollution and hospital admission for cardiovascular and respiratory diseases. JAMA 295: 1127-1134.

FEEMA - FUNDAÇÃO ESTADUAL DE ENGENHARIA DO MEIO AMBIENTE. 2004. Inventário de Fontes Emissoras de Poluentes Atmosféricos da Região Metropolitana do Rio de Janeiro. Rio de Janeiro, 144 p.

FINLAYSON-PITTS BJ AND PITTS JR JN. 2000. Chemistry of the upper and lower atmosphere: theory, experiments and applications. Elsevier Inc., San Diego, 969 p.

GERALDINO CGP, MARTINS EM, SILVA CM AND ARBILLA G. 2017. An Analytical Investigation of Ozone Episodes in Bangu, Rio de Janeiro. Bull Environ Contam Toxicol 98: 632-637.

GIODA A, AMARAL BS, MONTEIRO ILG AND SAINT'PIERRE TD. 2011. Chemical composition, sources, solubility, and transport of aerosol trace elements in a tropical region. J Environ Monitor 13: 2134-2142.

GIODA A, VENTURA LMB, RAMOS MB AND SILVA MPR. 2016. Half Century Monitoring Air Pollution in a Megacity: a Case Study of Rio de Janeiro. Water Air Soil Pollut 227: 1-17.

GODOY MLDP, GODOY JM, ROLDÃO LA, SOLURI DS AND DONAGEMMAB RA. 2009. Coarse and Fine Aerosol Source Apportionment in Rio de Janeiro, Brazil. Atmos Environ 43: 2366-2374.

GRYPARIS A, DIMAKOPOULOU K, PEDELI $\mathrm{X}$ AND KATSOUYANNI K. 2014. Spatio-temporal semiparametric models for $\mathrm{NO}_{2}$ and PM10 concentration levels in Athens, Greece. Sci Total Environ 479-480: 2130.

HE G, FAN M AND ZHOU M. 2016. The effect of air pollution on mortality in China: Evidence from the 2008 Beijing Olympic Games. J Environ Econ \& Management 79: 18-39.

IBGE - INSTITUTO BRASILEIRO DE GEOGRAFIA E ESTATÍSTICA. 2012. Estimativas de população, 2012. Disponível em: <http:/www.ibge.gov.br/home/estatistica/ economia/pibmunicipios/2011/default xls.shtm>. (Acesso em Julho, 2016).

INEA - INSTITUTO ESTADUAL DO AMBIENTE. 2016a. Relatório da Qualidade do Ar, Ano Base 2015. Disponível em: <http://www.inea.rj.gov.br/cs/groups/public/@inter dimfis_gear/documents/document/zwew/mtmx/ edisp/ inea0131852.pdf $>$. (Acesso em Julho, 2016).

INEA - INSTITUTO ESTADUAL DO AMBIENTE. 2016b. Inventário de emissões de fontes veiculares da Região Metropolitana do Rio de Janeiro, ano-base 2013. Disponível em: <http:/www.inea.rj.gov.br/cs/groups/ public/@inter/documents/document/zwew/mti3/ edisp/ inea0127421.pdf $>$. (Acesso em Agosto, 2016).

JHUN I, OYOLA P, MORENO F, CASTILLO M AND KOUTRAKIS P. 2013. PM2.5 mass and species trends in Santiago, Chile, 1998 to 2010: The impact of fuel-related interventions and fuel sales. J Air Waste Manag Assoc 63: 161-169.

LEYS JF, HEIDENREICH SK, STRONG CL, MCTAINSH GH AND QUIGLEY S. 2011. PM $_{10}$ concentrations and mass transport during "Red Dawn" - Sydney 23 September 2009. Aeolian Res 3: 327-342.

LI Y, WANG W, KAN H, XU X AND CHEN B. 2010. Air quality and outpatient visits for asthma in adults during the 2008 Summer Olympic Games in Beijing. Sci Total Environ 408: 1226-1227.

LUNA A, PAREDES M, OLIVEIRA G AND CORREA S. 2014. Prediction of ozone concentration in tropospheric levels using artificial neural networks and support vector machine at Rio de Janeiro, Brazil. Atmos Environ 98: 98104.

LV B, ZHANG B AND YUQI B. 2016. A systematic analysis of $\mathrm{PM}_{2.5}$ in Beijing and its sources from 2000 to 2012. Atmos Environ 124: 98-108.

MARTINS EM, NUNES ACL AND CORRÊA SM. 2015. Understanding Ozone Concentrations During Weekdays and Weekends in the Urban Area of the City of Rio de Janeiro. J Braz Chem Soc 26: 1965-1975.

RIO2016 - RIO DE JANEIRO OLYMPIC GAMES WEBSITE. 2016. Available at: <https://www.rio2016. $\mathrm{com} />$ (Accessed in May, 2016).

RODRÍGUEZ-COTTO RI, ORTIZ-MARTÍNEZ MG, RIVERA-RAMÍREZ E, MATEUS VL, AMARAL BS, JIMÉNEZ-VÉLEZ BD AND GIODA A. 2014. Particle pollution in Rio de Janeiro, Brazil: Increase and decrease of pro-inflammatory cytokines IL-6 and IL- 8 in human lung cells. Environ Pollut 194: 112-120.

RUNDELL KW. 2012. Effect of air pollution on athlete health and performance. Br J Sport Med 46: 407-412

SEA - SECRETARIA ESTADUAL DO AMBIENTE. 2011. Inventário de Emissões Atmosféricas por Veículos Automotores do Estado do Rio de Janeiro. Disponível em: <http://www.ltc.coppe.ufrj.br/images/projetos/ 
Relat\%C3\%B3rio Inventario 2011.pdf>. (Acesso em Agosto, 2016).

SILVA CM, SILVA LL, CORRÊA SM AND ARBILLA GA. 2018. minimum set of ozone precursor volatile organic compounds in an urban environment. Atmos Pollut Res 9: 369-378.

SILVA DBN, MARTINS EM AND CORREAA SM. 2016. Role of carbonyls and aromatics in the formation of tropospheric ozone in Rio de Janeiro, Brazil. Environ Monit Assess 188: 289-301.

SOLURI DS, GODOY MLDP, GODOY JM AND ROLDÃO LA. 2007 Multi-site $\mathrm{PM}_{2.5}$ and $\mathrm{PM}_{2.5-10}$ Aerosol Source Apportionment in Rio de Janeiro. Brazil. J Braz Chem Soc 18: 838-845.

SOUSA SIV, PIRES JCM, FORTES JDN, MARTINS EM, MARTINS FG AND ALVIM-FERRAZ MCM. 2012. Short-term effects of air pollution on respiratory morbidity at Rio de Janeiro - Part I. Environ Int 43: 1-5.

TSURUTA F, CARVALHO NJ, SILVA CM AND ARBILLA G. 2017. Air Quality Indexes in the City of Rio de Janeiro During the 2016 Olympic and Paralympic Games. J Braz Chem Soc 29(6): 1291-1303.

U.S.EPA - UNITED STATES ENVIRONMENTAL PROTECTION AGENCY. 2012. Responses to Significant Comments on the 2012 Proposed Rule on the National Ambient Air Quality Standards for Particulate Matter. Available at: < http://www.epa.gov/ttn/naaqs/standards/ $\mathrm{pm} /$ data/20121214rtc.pdf $>$. (Accessed in May, 2016).

VASSILAKOS CH, SARAGA D, MAGGOS TH, MICHOPOULOS J, PATERAKI S AND HELMIS CG. 2005. Temporal variations of PM2.5 in the ambient air of a suburban site in Athens, Greece. Sci Total Environ 349: 223-231.
VENTURA LMB, DE OLIVEIRA FP, SOARES LM, LUNA AS AND GIODA A. 2017a. Evaluation of air quality in a megacity using statistics tools. Meteorol Atmos Phys 130: $1-10$.

VENTURA LMB, MATEUS VL, ALMEIDA ACSL, WANDERLEY KB, TAIRA FT, SAINT'PIERRE TD AND GIODA A. 2017b. Chemical composition of fine particles (PM2.5): water-soluble organic fraction and trace metals. Air Qual Atmos Health 10: 845-852.

VENTURA LMB, RAMOS MB, FERNANDES LC, SOARES CM AND SANTOS JO. 2016. Rio 2016: Qualidade do ar e condições meteorológicas nos locais de competição. Ineana 4: 6-47.

WILSON RC, FLEMING ZL, MONKS PS, CLAIN G, HENNE S, KONOVALOV IB, SZOPA S AND MENUT L. 2012. Have primary emission reduction measures reduced ozone across Europe? An analysis of European rural background ozone trends 1996-2005. Atmos Chem Phys 12: 437-454.

\section{SUPPLEMENTARY MATERIAL}

Table SI - Olympic stations and sports modalities.

Table SII - Meteorological data of Olympic stations from 2013-2015.

Figure S1 - Wind rose from 2013-2015 data of the stations: 1 - Jacarepaguá; 2 - Recreio dos Bandeirantes; 3 - Campos dos Afonsos; 4 - Gericinó; 5 - Urca; 6 - Leblon; 7 - Lagoa; 8 Maracanã; 9 - Engenho de Dentro; 10 - Downtown.

Figure S2 - Boxplot for the $\mathrm{PM}_{10}$ and $\mathrm{PM}_{2.5}$ concentrations for each sport regions from 2013 to 2015. 